EWA MŁynaRCZYK

Uniwersytet Pedagogiczny

Kraków, Polska

werwino@gmail.com

https://doi.org/10.17234/9789531755139.20

\title{
FRAZEOLOGIZMY I PRZYSŁOWIA RZEMIEŚLNICZE Z KOMPONENTEM ANIMALISTYCZNYM
}

\begin{abstract}
Jednostki wielowyrazowe motywowane realiami rzemieślniczymi i zawierające w swym składzie nazwy zwierząt odnoszą się głównie do rzemiosł skórniczych (garbarstwo, kuśnierstwo, szewstwo, rymarstwo), spożywczych (rzeźnictwo, młynarstwo) oraz rzemiosła kowalskiego. Analiza tych jednostek jako nośników językowego obrazu świata pozwala na odtworzenie wielu utrwalonych w języku stereotypowych sądów, w których decydującą rolę odgrywa wartościowanie z perspektywy wykonawcy i/lub obserwatora pracy rękodzielniczej.
\end{abstract}

Słowa kluczowe: frazeologia rzemieślnicza, frazeologia animalistyczna, językowy obraz świata, stereotypy, wartościowanie

Wielowyrazowe jednostki słowne motywowane realiami rzemieślniczymi (dalej: FRZ) to ważna kulturowo część składowa polskiego zasobu frazeologicznego ${ }^{1}$. Należą do niej jednostki zawierające w swym składzie nazwę rzemieślnika (np. szewc bez butów chodzi), wyraz od niej derywowany (np. szewska pasja) lub komponent nazywający element rzeczywistości związany z wykonywaniem danego rzemiosła (np. być między młotem a/i kowadłem). Należą tu także multiwerbizmy, które nie mają elementu jednoznacznie kojarzącego się z realiami rzemieślniczymi, ale wskazuje na nie ich obrazowość (np. Gdzie cienko, tam się rwie). Analiza znaczenia genetycznego wymienionych typów jednostek frazeologicznych (dalej JF) ${ }^{2}$, stanowi podstawę odtworzenia elementów językowego obrazu świata $(\mathrm{JOS})^{3} \mathrm{w}$ zakresie realiów rzemieślniczych, które współczesnemu użytkownikowi języka nie zawsze są znane ${ }^{4}$.

$1 \quad$ Frazeologizmy te stały się przedmiotem opisu w odrębnej monografii E. Młynarczyk (2010) pt. Nie święci garnki lepią. Obraz rzemiosła utrwalony w polskiej frazeologii. Jednostki frazeologiczne omawiane w niniejszym artykule stanowią część zasobu analizowanego w tejże monografii. W pewnym stopniu wykorzystuję także poczynione tam ustalenia.

2 Biorę pod uwagę różne typy utrwalonych społecznie połączeń słownych, które cechuje asumaryczność znaczeniowa, obrazowość i ekspresywność: zarówno frazeologizmy, ustabilizowane porównania, jak i samodzielne składniowo przysłowia.

3 Teoretyczne koncepcje oraz praktyczne zastosowania badań, w których najważniejszą kategorią badawczą jest językowy obraz świata (JOS), można znaleźć w licznych opracowaniach m.in. J. Anusiewicz (1995) Lingwistyka kulturowa. Zarys problematyki; J. Bartmiński (2004) Językowy obraz świata; J. Bartmiński (2009) Językowe podstawy obrazu świata.

4 Znaczna część zebranych jednostek ma we współczesnej polszczyźnie charakter recesywny. W analizie JF przyjmuję jednak panchroniczny punkt widzenia, pozwalający pokazać prawidłowości w formułowaniu sądów i społecznie utrwalonych przekonań (Łozowski 1999: 40). 
Wśród jednostek należących do FRZ znalazło się sporo takich, które w swym składzie zawierają nazwy zwierząt. Swą obrazowością nawiązują one głównie do rzemiosł skórniczych: garbarstwa, kuśnierstwa, szewstwa. Część FRZ z komponentem animalistycznym odnosi się do rzemiosł spożywczych - rzeźnictwa i młynarstwa. Jeszcze inne JF związane są tematycznie z kowalstwem. Wśród JF dotyczących pozostałych dziedzin rzemiosł jednostki z komponentem animalistycznym występują rzadko i dość przypadkowo, nie dając podstaw do opisu pewnych prawidłowości w sposobach widzenia świata.

Analiza zebranych $\mathrm{JF}^{5}$ jako nośników językowego obrazu świata pozwala na odtworzenie wielu utrwalonych w języku sądów i przekonań osób trudniących się rzemiosłem lub korzystających z niego na temat roli zwierząt w życiu człowieka.

Większość zebranych JF prezentuje użytkowy punkt widzenia na świat zwierząt. Jest on szczególnie widoczny wśród połączeń wyrazowych, u podstaw których legły realia związane z rzemiosłami skórniczymi, jak garbarstwo, kuśnierstwo lub szewstwo. JF z komponentem animalistycznym dokumentują postrzeganie przez nich zwierząt przez pryzmat możliwości pozyskania drogiego surowca - skóry. Takie podłoże mają m.in. JF: Od wołu niczego spodziewać się nie można prócz skóry i mięsa (NKP III: 761); Z jednego wotu / barana dwóch skór nie dra (NKP III: 218); chciatby mieć z jednego lisa dwie skóry (NKP II: 306); Goniq lisa nie dla mięsa, ale dla skóry (NKP II: 307); Umrze lis, a skóra zostanie (NKP II: 310); Jaki wót, taka skóra, jaka mać, taka córa (SFzP: 49); Na sobola więcej waża niż na tchórza, bo lepszq skórę ma (NKP III: 264); skupili się by liszki do kuśnierza (NKP III: 224). Z pozyskiwaniem skóry końskiej wiąże się wyrażenie rzeczownikowe ${ }^{6}$ koń ze Skotnik (NKP III: 211), odnoszone do starego, przeznaczonego na zabicie konia, ponieważ w podkrakowskiej wsi, Skotnikach, mieszkali garbarze kupujący takie zwierzęta na skórę (PPoN: 186).

Znielegalnym pozyskiwaniem skóry wiąże się powiedzenie Szewc to pierwszy po hyclu (NKP III: 394). Jak pisze J. Krzyżanowski, przysłowie to wywodzi się ze zwyczaju łupienia zdechłych koni przez szewców w celu uzyskania skóry - zwyczaju kojarzonego z zajęciem hyclów, zajmujących się łapaniem i uśmiercaniem bezpańskich psów, przez co byli oni bardzo nisko oceniani w ludzkich społecznościach (Krzyżanowski 1960 I: 501).

O tym, jak cennym surowcem była skóra, przekonują jednostki służące konceptualizacji sądu 'robić przedwczesne plany; dzielić zawczasu zyski', współcześnie repre-

5 Omawiane jednostki frazeologiczne pochodzą z kilku zbiorów frazeograficznych, głównie z Nowej księgi przystów $i$ wyrażeń przystowiowych polskich, pod red. J. Krzyżanowskiego (dalej: NKP), a także ze słowników: S. Skorupka, Słownik frazeologiczny języka polskiego (SFJP); A. Kłosińska, E. Sobol, A. Stankiewicz, Stownik frazeologiczny PWN z przystowiami [SFzP]; S. Bąba, J. Liberek, Słownik frazeologiczny współczesnej polszczyzny (SFWP), P. Müldner-Nieckowski, Wielki słownik frazeologiczny języka polskiego: wyrażenia, zwroty, frazy (SMN). Rozwiązania skrótów i pełny opis bibliograficzny słowników znajduje się na końcu artykułu, w lokalizacji jednostek frazeologicznych podaję skrót słownika numer tomu i strony, np. (NKP III: 211). Podaję zazwyczaj postać inwariantu przyjętego w danym opracowaniu, ale uzupełniam ją o komponenty wariantywne (wynikające z dokumentacji) ważne dla odtworzenia JOS.

${ }_{6}$ W niniejszym artykule przyjmuję typologię związków frazeologicznych zaproponowaną przez A.M. Lewickiego i Pajdzińską (Lewicki i Pajdzińska: 1993: 308-313). 
zentowane przez zwrot dzielić skórę na niedźwiedziu (SFzP: 93). Materiał zgromadzony w NKP ukazuje społeczne przekonanie, że na zyski ze skóry zwierzęcej liczyli głównie rzemieślnicy: Jeszcze skóra na baranie, a już kuśnierz / szewc / rzeźnik / masarz pije na niq (NKP III: 213, 214); Jeszcze skóra na wole, a już buty szyja (NKP III: 214); Chcecie skórę zanieść do garbarza, podczas gdy niedźwiedź jeszcze w lesie (NKP III: 213).

Sposób postrzegania świata zwierzęcego z perspektywy użytkowej spowodował, że w wielu JF dokumentujących realia rzemieślnicze nazwa zwierząt metonimicznie oznacza skórę tego zwierzęcia, zwłaszcza w połączeniach wyrazowych obrazujących zabiegi fałszerskie (m.in. farbowanie), jakich dopuszczano się ze względu na wysoką cenę niektórych skór, np. Nie będzie soból z czarnego kota (NKP III: 264); Nie ujdzie kuna za sobola (NKP II: 247); Psi pysk sobolim ogonem lamowany (NKP II: 908); znam sie na kopconych sobolach (NKP III: 265); Nie ujdzie kuna za sobola (NKP II: 247); Nie będa ze psiej skóry jałowicze buty (NKP I: 218).

Kojarzenie zabiegu barwienia skór $\mathrm{z}$ fałszem przetrwało w znanym do dziś wyrażeniu farbowany lis (SFzP: 214), metaforycznie nazywającym człowieka fałszywego, nieszczerego, oszusta.

Wysoka cena skór zwierzęcych spowodowała specyficzny sposób wykańczania i zdobienia wyrobów kuśnierskich:

W dawnej Polsce okrycia futrzane noszono zawsze pod wierzch z tkaniny. Wyjątek stanowiły jedynie kożuchy baranie, noszone mizdrą ${ }^{7}$ na wierzch. Kołnierz, wyłogi, czyli bramowania i mankiety wykonywano zawsze z lepszych gatunków skór futerkowych aniżeli całe podbicie (Turnau 1983: 63).

Zwyczaj podszywania odzieży (płaszczy, futer, czapek) droższym futrzanym podbiciem (Hensel et al. III: 280-281) został odzwierciedlony we frazeologizmach z komponentem animalistycznym (w znaczeniu 'skóra ze zwierzęcia'): lisem podszyty (NKP II: 307) i tchórzem podszyty (NKP III: 513), w których stereotypowe cechy przypisywane zwierzętom stały się podstawą metaforycznych znaczeń tych jednostek: lisem podszyty 'chytry, sprytny'; tchórzem podszyty 'lękliwy, tchórzliwy's.

Stereotypowe cechy przypisywane zwierzętom wykorzystane zostały również w innych JF obrazujących sposób szycia odzieży futrzarskiej Gdzie lwiej skóry nie staje, lisia nadstawić (NKP II: 307) ‘czego nie można zdobyć siła, trzeba nadrobić sprytem', a także

Mizdra 'w garbarstwie: wewnętrzna, przymięsna strona skóry' [SJPD].

8 Metafora motywowana dawnymi realiami kuśnierskimi legła u podłoża serii związków wyrazowych o strukturze coś [jest] czymś podszyte (SFzP: 370) o wspólnym elemencie znaczeniowym 'ktoś lub coś ma ukryte [niewidoczne od razu] cechy człowieka lub rzeczy': diabłem podszyty (NKP I: 429) 'zły', ktoś [jest] podszyty tchórzem/dzieckiem itp. (SFzP: 370) 'ktoś ma cechy tchórza, dziecka itp.'; ktoś (jest) lękiem/strachem podszyty [tamże] ‘o kimś lękliwym, tchórzliwym'. Jako żartobliwa analogia został utworzony frazeologizm wiatrem podszyty (SFzP: 610) utrwalony we współczesnej polszczyźnie jako określenie lekkiej, lichej odzieży, przepuszczającej zimno. 
mina jest zucha, z tchórza opucha (NKP II: 489) ${ }^{9}$. Podobny mechanizm zmian semantycznych legł u podstaw metaforyzacji wyrażeń oznaczających osobę tchórzliwą: zajęcza skórka (NKP III: 820); zuch z baraniej skóry (NKP III: 919).

Frazeologizmy i przysłowia z komponentem animalistycznym przechowywały także pamięć o wyrobach uzyskiwanych ze skóry zwierzęcej, m.in. butach: skóra / skórka na buty (SMN: 93); Skórka na buty, język na podeszwy (NKP III: 218) ${ }^{10}$.

Innym wyrobem był pergamin używany do przepisywania ksiąg i dokumentów, wyrabiany ze skóry cielęcej, koźlej lub baraniej (Hensel et al. II: 138). Realia te są składnikiem obrazowości JF: Biada skórze, na której się pisać ucza (NKP III: 211); Lepszy jest zawżdy żywy glos niż zdechta skóra, co ja na pargamin wyprawuja (NKP I: 634), a także zwrot używany do dziś - na wołowej skórze by nie spisat (SFzP: 480) 'czegoś jest tak dużo, że trudno wszystko wymienić, spisać' ${ }^{11}$. NKP w dokumentacji tej jednostki, zarejestrowanej w postaci Nie spisałby tego na wołowej skórze (NKP III: 215), podaje przykłady z wymienialnym komponentem przymiotnikowym nazywającym różne gatunki skór: bawola / bycza oraz żartobliwie psia (tamże).

Kilka paremii przypomina o innych wyrobach wytwarzanych ze skóry - instrumentach muzycznych, m.in. bębnach (Turnau 1983: 29): Po śmierci osta skórę na bęben obróca [NKP III: 216], w tym bębnach wojskowych, których słuchanie oznacza metonimicznie 'być żołnierzem' w JF: stuchać psiej skóry (SL V: 291); Kto nie stucha ojca, matki, ten postucha psiej skóry (SFzP: 490) 'kto nie słucha rodziców, ten nauczy się posłuchu w wojsku'.

Użytkowy punkt widzenia, podobnie jak w analizowanych wyżej jednostkach, prezentują również te, które w swym znaczeniu genetycznym odnoszą się do jednego z usługowych rzemiosł spożywczych - rzeźnictwa, zwanego inaczej masarstwem ${ }^{12}$. Osoby parające się tym rzemiosłem zajmowały się skupywaniem zwierząt oraz ich ubojem, sprzedażą mięsa, a także własnoręcznie wykonanych wyrobów wędliniarskich.

Wiele JF z komponentem animalistycznym odzwierciedla etap pozyskiwania zwierząt na ubój, poprzez skupywanie ich na targu albo bezpośrednio w domu właściciela:

9 Opucha, inaczej opuszka to rodzaj wykończenia czapek lub innych ubiorów, często szytego z droższej skóry niż cały ubiór (Turnau 1983: 64), co znalazło odzwierciedlenie w JF opucha droższa kożucha (NKP II: 183) 'dodatek przewyższa wartością zasadniczy przedmiot'.

10 O tym, że skóry jako surowca używał szewc, świadczą także liczne inne JF [bez komponentu animalistycznego]: leci jak szwiec po skóre (NKP III: 393); od szewca skórę kupować (NKP II: 250); Smolarz smoła, szewc skórami śmierdzi (NKP III: 259); Szewc do skóry, a rzeźnik do mięsa (NKP III: 394); Szwiec, który się na skóry zadluży, tedy podeszwami wypłaca (NKP III: 395); Szwiec skóry, a krawiec igly pilnuje (NKP III: 395); Tyle szewca zysku, co wyciagnie skóry w pysku (NKP III: 395).

11 Według Krzyżanowskiego zwrot ten miał charakter ironiczny, ponieważ pergamin wyrabiano ze skóry cienkiej i delikatnej, a nie z wołowej - zbyt grubej na materiał piśmienniczy [Krzyżanowski 1965: 266].

12 Nazwy te pochodzą od dwóch nazw zawodu: rzeźnik, nazwa etymologicznie nawiązująca do uboju zwierząt [derywat od psł. *rězati, pol. rzezać 'ciąć, rżnąć, SEBor] i masarz - nazwa zawierająca odniesienie do obiektu pracy - mięsa, będąca zapożyczeniem z czeskiego masař 'rzeźnik, kat', od psł. *męso, SEBor. 
Wiedza rzeźnicy o dobrej jatowicy (NKP I: 823); Po thuste ciele $i$ do domu trafia, a chudego i na targu nie kupia (NKP I: 314), Nie chce ja pisarza ani studenta, wole ja masarza/rzeźnika, co wozi cielęta (NKP II: 942).

Komponenty animalistyczne w analizowanych JF wskazują na konkretne gatunki zwierząt hodowlanych najczęściej przeznaczanych na rzeź: patrzy jak krowa na rzeźnika, w wariantach udokumentowanych w NKP: patrzy jak wót / koza / owca / byk na rzeźnika/masarza (NKP II: 832); jak koza do rzeźnika idzie (NKP I: 805); spaśny ['upasiony, tłusty'] jak byk na masorza (NKP II: 828); Każde cielę znajdzie rzeźnika (NKP I: 313), Nierada by koza do rzeźnika, ale musi (NKP III: 508).

Paremie wskazują także kryteria, jakimi kierowano się, decydując o losie zwierząt: Wołu do rzeźnika, a krowe do byka (NKP III: 764); Tego wotu do rzeźnika, którego krowa zbije (NKP III: 760). Powiedzenie $W$ jatce wszystkie krowy sq woły (NKP I: 835) przypomina, że mięso krowie nazywane jest wolowym.

Utrwalone połączenia słowne zawierają także aspekt wartościujący. W ich świetle najbardziej cenione było mięso cieląt, o czym świadczą przysłowia: Więcej cieląt na szlachtuzie jako krów, więcej młodych na cmentarzu jako starych (NKP I: 314); Więcej cielat $w$ jatkach bywa niż starych wolów (NKP I: 314), a najmniej - mięso kozie, co ilustruje powiedzenie Bodajbyś byt lepiej kozie topatki przedawat (NKP II: 173). Złorzeczenie to zostało prawdopodobnie skierowane do syna rzeźnika, robiącego karierę wojskową ${ }^{13}$. Niska ocena wartości mięsa z kóz wiąże się ze stereotypowym postrzeganiem tych zwierząt jako symbolu biedy, co potwierdzają JF, m.in. Koza - krowa biydnych ludzi (NKP II: 175); Koza nie bydto, dziewka nie czeladź (tamże).

Zwierzęta przeznaczone na zabicie, niemające na to żadnego wpływu, kojarzone były z rezygnacją, biernym poddaniem się decyzjom innych. Konotacje te legły u podstaw JF stosowanych wobec osób potulnych, takich, które z rezygnacją przyjmują nawet najgorszy los: prowadzony na rzeź (baran); prowadzona na rzeź (owieczka) (SFJP II: 84); dać sięjak baran prowadzić na rzeź (tamże).

Frazeologia z komponentem animalistycznym odzwierciedla również inny aspekt dawnego sposobu uprawiania rzeźnictwa. Uboju i sprzedaży mięsa dokonywano w jatkach, czyli budkach targowych, wokół których gromadziły się psy zwabione możliwością zdobycia mięsnych odpadków. Realia te stały się podstawą frazeologizmów porównawczych: chodzi jak pies po jatkach (NKP I: 280); znarowit sięjak pies do jatki (NKP III: 916); wtóczq się jako psi od jatki do jatki (NKP III: 720); zaglada jak pies do jatki (NKP III: 817); przywykła jak suczka do jatek (NKP II: 1140).

Zdecydowanie inny obraz zwierząt utrwalały JF z komponentem animalistycznym dotyczące młynarstwa. Młynarze należeli do osób dobrze sytuowanych, dodatkowe dochody przynosiły im bowiem gospodarstwa przymłynne, w których hodowano sporo zwierząt (Baranowski 1977: 62-63). Wedle stereotypowego sądu obywało się to ma-

13 Krzyżanowski za Goldsteinem podaje wyjaśnienie, że powiedzenie to było skierowane do Jana Witta, syna rzeźnika z Kamieńca Podolskiego, który dorobił się stopnia generała [NKP II: 173]. 
łym kosztem ze względu na obfitość pożywienia dla zwierząt, jakim były odpady z przerobu zboża na mąkę. Sąd ten obrazuje przysłowie Młynarskie wieprze rozkurzem się tuczq (Wesołowska 1969: 201) ${ }^{14}$.

Przekonanie o dobrobycie zwierząt hodowanych przez młynarza ilustrują przede wszystkim JF o charakterze porównawczym, najczęściej żartobliwe: tyje jak młynarska świnia (NKP III: 555); syty jak mlynarska kura (NKP III: 367); delikatny jak mlynarski pies (NKP I: 419), ale także ironiczne: mizerny jak koń mbynarski (NKP II: 495); głodny jak mlynarska kura (NKP I: 632); majóm głód, jak młynarzowa gowiydź (NKP I: 666).

To stereotypowe wyobrażenie stało się także składnikiem priameli obrazujących ludowe postrzeganie dobrobytu: Diabet nie chciat być kucharzem, furmanem i mam$\mathrm{kq}$, ale chciat być mlynarskim wieprzem, urzędniczym koniem i księża kucharka (NKP I: 427); Babusina wnuczka, mlynarska suczka, ekonomski kon maja wygody / dobrze się maja (NKP I: 33); Młynarska świnia, księża gospodynia, ekonomski koń - to jedno (NKP II: 510), w wariantach udokumentowanych w NKP: Wieprz mlynarski, koń ekonomski i księża gospodyni nigdy nie sq chude / dobrze się maja; Młynarska krowa, dziewka popowa i ekonomska kobyła nigdy głodna nie była.

W tym kontekście jasne staje się znaczenie paremii Kobyła ze młyna nie godzi się do gazdy (NKP II: 90), wyrażającej przekonanie o dużej różnicy między sytym i wygodnym życiem młynarskich zwierząt a losem koni u gospodarza (gazdy), skazanych na ciężką pracę.

Osobną grupę wśród JF z komponentem animalistycznym stanowią te, które odnoszą się do kowalstwa, dziedziny rzemiosła kojarzonej z podkuwaniem koni, czyli przybijaniem podków do kopyt, aby wzmocnić siłę zwierzęcia i dać mu możliwość stabilnego poruszania się po każdym rodzaju gruntu. W ustabilizowanych połączeniach wyrazowych utrwalony został obraz tego właśnie zajęcia kowala: Konia kuja, żaba noge podstawia (SFzP: 179); [Kowal] Kowol kobyte kut, kobyla kowola kopta, kowol klón (NKP II: 172), a także dla ufnala konia zepsować ${ }^{15}$ (NKP II: 118) ${ }^{16}$.

W realiach związanych z podkuwaniem kopyt końskich ma swoje źródło frazeologizm kuty na cztery nogi (SFWP 333), znany też w wariancie kuty na wszystkie cztery nogi/kopyta (NKP II: 261), odnoszony do człowieka sprytnego, zaradnego i doświadczonego życiowo. Podobne konotacje niesie powiedzenie stosowane jako rada dla kogoś niezaradnego idź do kowala i daj się podkuć (NKP II: 981).

Frazeologia obrazuje także społeczne przekonanie (wynikające oczywiście z doświadczenia), że zakładanie podków jest zabiegiem stosowanym wyłącznie u koni. Wykonywanie tej czynności w stosunku do innych zwierząt jest przedstawiane w paremiach szyderczo jako zachowanie niewłaściwe, świadczące o czyjejś głupocie: jak

\footnotetext{
14 Rozkurz 'część ziarna potrącana klientom przez młynarzy na rozchód [2-3\%]' [Wesołowska 1969: 279].

15 Hufnal, ufnal 'gwóźdź służący do przybijania podkowy koniom' (SJPD).

16 To samo znaczenie ma powiedzenie Dla gwoździa ginie podkowa (NKP I: 774).
} 
w Osieku, gdzie kozy kuja (NKP II: 743); W Pacanowie, gdzie kozy kuja (NKP II: 177) ${ }^{17}$; zgrabny jak krowy do podkowy (NKP III: 863); Jak kozy kuli, a psy tytkami szczekaty (NKP II: 174) ${ }^{18}$.

Frazeologizmy i przysłowia z komponentem animalistycznym mające swe źródła w realiach rzemieślniczych są kolejnym świadectwem językowego antropocentryzmu przybierającego tu szczególnie jaskrawą postać. Osoby parające się rzemiosłem widziały w zwierzętach źródło swoich dochodów. W zależności od dziedziny rzemiosła stanowiły je: skóra - jako surowiec dla garbarzy, kuśnierzy i szewców lub mięso - jako surowiec i towar dla rzeźników / masarzy. Kowale natomiast zarabiali na podkuwaniu koni, szczególnie zimą, kiedy poruszanie się utrudniała śliska powierzchnia, a podkowy szybciej się ścierały ${ }^{19}$. Odmienność frazeologizmów dotyczących młynarstwa jest trochę pozorna, bowiem zwierzęta postrzegane są w nich również w kontekście materialnego statusu właściciela - świadczyły o jego zamożności.

Decydującą rolę w omówionych frazeologizmach i przysłowiach odgrywa zatem użytkowy punkt widzenia człowieka, determinujący zarówno to, które nazwy zwierząt stały się ich komponentami, jak i to, w jaki sposób zostały w nich przedstawione.

\section{LITERATURA}

Anusiewicz, Janusz. 1995. Lingwistyka kulturowa. Zarys problematyki. Wrocław: Wydawnictwo Uniwersytetu Wrocławskiego.

Baranowski, Bogdan. 1977. Polskie mlynarstwo. Wrocław - Warszawa - Kraków - Gdańsk: Ossolineum.

Bartmiński, Jerzy. 2009. Jęzkowe podstawy obrazu świata. [wyd. 3]. Lublin: Wydawnictwo Uniwersytetu Marii Curie-Skłodowskiej.

Historia kultury materialnej Polski w zarysie. 1978. Hensel, Witold; Pazdura, Jan (red.). Od XIII do XV wieku. Rutkowska-Płachcińska Anna (red.). t. II.; Od XVI do połowy XVII wieku. Keckowa, Antonina et al. (red.). t. III. Wrocław - Warszawa - Kraków - Gdańsk: Ossolineum.

Jęzkowy obraz świata. 2004. Bartmiński, Jerzy (red.). [wyd. 2]. Lublin: Wydawnictwo Uniwersytetu Marii Curie-Skłodowskiej.

Lewicki, Andrzej Maria; Pajdzińska, Anna. 1993. Frazeologia. W: Wspótczesny język polski. Bartmiński, Jerzy (red.). Wrocław. 307-326.

$17 \quad$ Osiek i Pacanów to nazwy miejscowości traktowanych [na równi z kilkoma innymi] w tych i w innych paremiach jako symbol głupoty. W świadomości użytkowników polszczyzny nazwa Pacanów jest mocno utrwalona dzięki serii bajek Kornela Makuszyńskiego o Koziołku Matołku, który chciał trafić do Pacanowa, kierując się zasłyszanym powiedzeniem „W Pacanowie kozy kują”.

18 Jest to odpowiedź 'nigdy' na pytanie „Kiedy to było?”.

19 Świadczy o tym przysłowie Jak na drodze lód, to kowalom miód (NKP II: 171). 
Łozowski, Piotr. 1999. Panchronia, czyli językoznawstwo bez synchronii. W: Przeszłość w językowym obrazie świata. Pajdzińska, Anna et al. (red.). Lublin: Wydawnictwo Uniwersytetu Marii Curie-Skłodowskiej. 25-50.

Madrej głowie dość dwie słowie. 1960. Krzyżanowski, Juliusz (red.). Trzy centurie przysłów polskich. t. I.: Dwie nowe centurie przystów polskich. t. II.: Warszawa: Państwowy Instytut Wydawniczy.

Młynarczyk, Ewa. 2013. Nie święci garnki lepią. Obraz rzemiosła utrwalony w polskiej frazeologii. Kraków: Wydawnictwo Uniwersytetu Pedagogicznego.

Turnau, Irena. 1983. Polskie skórnictwo. Wrocław - Warszawa - Kraków - Gdańsk - Łódź: Ossolineum.

Wesołowska, Halina. 1969. Młynarstwo wiejskie Opolszczyzny od XVIII do XX wieku. Opole: Wydawnictwo Instytutu Śląskiego w Opolu.

\section{SŁOWNIKI}

Bąba, Stanisław et al. 2002. Słownik frazeologiczny współczesnej polszczyzny. Warszawa: Wydawnictwo Szkolne PWN. [SFWP]

Boryś, Wiesław. 2005. Słownik etymologiczny języka polskiego. Kraków: Wydawnictwo Literackie. [SEBor]

Darowski, Aleksander. 1874. Przysłowia polskie odnoszqce się do nazwisk szlacheckich i miejscowości. Poznań: Księgarnia J.K. Żupańskiego. [PPoN]

Kłosińska, Alina et al. 2005. Wielki słownik frazeologiczny PWN z przysłowiami. Warszawa: Wydawnictwo Naukowe PWN. [SFzP]

Linde, Samuel Bogumił. 1854. Słownik języka polskiego. t. I-VI. [wyd. 2]. Warszawa: Państwowy Instytut Wydawniczy. [SL]

Müldner-Nieckowski, Piotr. 2004. Wielki słownik frazeologiczny języka polskiego: wyrażenia, zwroty, frazy. Warszawa: Świat Książki. [SMN]

Nowa księga przysłów i wyrażé́ przysłowiowych polskich. 1969-1978. Krzyżanowski, Juliusz (red.). t. I-III.; Świrko, Stanisław (red.). t. IV. Warszawa: Państwowy Instytut Wydawniczy. [NKP]

Stownik folkloru polskiego. 1965. Krzyżanowski, Juliusz (red.). Warszawa: Wiedza Powszechna.

Skorupka, Stanisław. 1987. Słownik frazeologiczny języka polskiego. t. I-II. [wyd. 5]. Warszawa: Wiedza Powszechna. [SFJP]

\section{ŹRÓDŁA INTERNETOWE}

Słownik języka polskiego. http://doroszewski.pwn.pl/ [SJPD] 


\section{SAŽETAK}

\section{ZANATSKI FRAZEMI I POSLOVICE S ANIMALISTIČKOM SASTAVNICOM}

Višečlane jedinice u sastavu kojih su nazivi životinja i koje su motivirane realijama iz područja obrtništva odnose se uglavnom na kožarske obrte (štavljenje, krznarstvo, obućarstvo, remenarstvo, sedlarstvo), prehrambene (klanje, mlinarstvo), te na kovački obrt. Analiza tih jedinica kao nositelja jezične slike svijeta dopušta propitivanje mnogih stereotipnih sudova ustaljenih u jeziku, a u kojima ključnu ulogu igra vrednovanje iz perspektive vršitelja i/ili promatrača ručnoga rada.

Ključne riječi: zanatska frazeologija, animalistička frazeologija, jezična slika svijeta, stereotipi, vrednovanje 
